\title{
The Effect of Magic Book to Increase Interest in Learning Mathematics of Primary School Students
}

\author{
MaghfirohIzza Maulani*, Ashma Nur Hanifah Heninda Putri, Faddliyah, \\ Afifatul Muslimah, Aji Pangestu \\ Mathematics Education Department, Faculty of Math and Science, Universitas Negeri Yogyakarta, \\ Jl. Colombo No.1, Karang Malang, Caturtunggal, Depok, Sleman, Daerah Istimewa Yogyakarta 55281, Indonesia. Tel: +62-274-586168. \\ Email*: maghfirohizza9@gmail.com
}

\begin{abstract}
Elementary School is a place to understand all learning for the next level, especially mathematics. Mathematics is also considered difficult by elementary school students because of its abstract and complex nature, especially with the large number of mathematical formulas, and its lack of interest in learning. So that student interest in learning is reduced. One interesting way to learn mathematics is by using learning media. This research introduces MagicBook contains a collection of formulas and mathematical games. This Magicbook is arranged in such a way with an attractive layout and color. Sources of data obtained from questionnaires and direct research on elementary school students in one of the lessons in Yogyakarta. The data of this study were analyzed descriptively quantitative and qualitative. The results showed that the magic book learning media can increase elementary school students' mathematics learning interest.the effect.
\end{abstract}

Keywords: Magic Book, Learning mathematics, the effect, Primary School Students, Increase Interest

\section{INTRODUCTION}

Mathematics is a lesson which until now by students is still considered difficult. Whereas on the other hand, mathematics is an important subject in human life. Mathematics plays a role in almost all aspects even in today's technological and digital times. Unfortunately, based on data reported by the National Assessment of Educational Progress in 2013, less than $40 \%$ of students are proficient in mathematics (National Center for Education Statistics (NCES), in Nelson, Partner \&Zaslofsky, 2016) and test and evaluation results in in 2015 conducted by the Program for International Students Assessment (PISA) reported that out of 540,000 students, Indonesia was ranked 63 out of 70 countries for mathematics with a score of 386 indicating that the mathematical ability of Indonesian children was still low.

Many Indonesian children think that learning mathematics will succeed if they memorize a lot of formulas. Though learning mathematics is not enough just to memorize formulas, because such a method will only eliminate their opportunity to practice thinking. The wrong mindset about learning mathematics is what makes Indonesian children increasingly worried about mathematics. They think that mathematics is a lesson with a myriad of difficult formulas that are not easily memorized.

In Indonesia, students' success in completing their studies can be measured by holding a national exam. The purpose of holding a national exam is to assess the achievement of national competencies of graduates in certain subjects in a group of science and technology subjects. National exams are used as a means of determining the status of students, but the national exams which came into force in 2002 are designed for students who have occupied the highest class at a certain level of education.

There are several factors that affect the level of anxiety of grade VI elementary school students in facing UN - in this case specifically mathematics lessons -, such as excessive social demands, the existence of too high standards of success, individuals are less prepared in facing exams, the existence of patterns of thinking and negative perceptions of the situation or yourself, and besides these anxieties there is the most fundamental anxiety of the holding of the mathematics UN which is many formulas that must be understood at once memorized.

Seeing the anxiety of the sixth grade elementary school students in facing the math national exam, we would like to offer a solution that is a magic book which will help the students of the sixth grade elementary school in working on the math practice questions. Thus, students will more easily memorize the formula because students are accustomed to applying the formula into a mathematical problem.

\section{MATERIALS AND METHODS}

\section{Study area}

This research is aimed at 6th grade students to facilitate them in teaching and learning activities. In addition, this 
magic book learning media is perfect for those who will face exams, ranging from semester exams to national exams.

\section{Procedures}

Researchers must provide discussion in accordance with the stages that have been determined. Therefore, it can be seen that the implementation of the magic book learning media is as follows. The first step carried out by the researcher is to observe the 6th grade students to find out how the 6th grade students' learning interest is at the moment. The second step, researchers conducted data collection and provided a questionnaire containing learning material and learning material. The third step the researchers tested the use, at this stage the magic book learning media was carried out in Timoho,
Yogyakarta in grade 6 students totaling 30 students by administering questionnaires and post-test questions. This can be seen from the results of the questionnaire trial of the use of the magic book learning media has a percentage of $87 \%$. Researchers calculated using the classic complete formula with a percentage of $87 \%$, which means that the magic book learning media can give good results and can affect the increase in student learning intentions.

\section{Data analysis}

From our research we know that $81 \%$ of the 30 students who fill the questionnaire have a high interest in mathematics and $87 \%$ state that they are interested in magic books and can increase student interest in learning.

\section{RESULTS AND DISCUSSION}
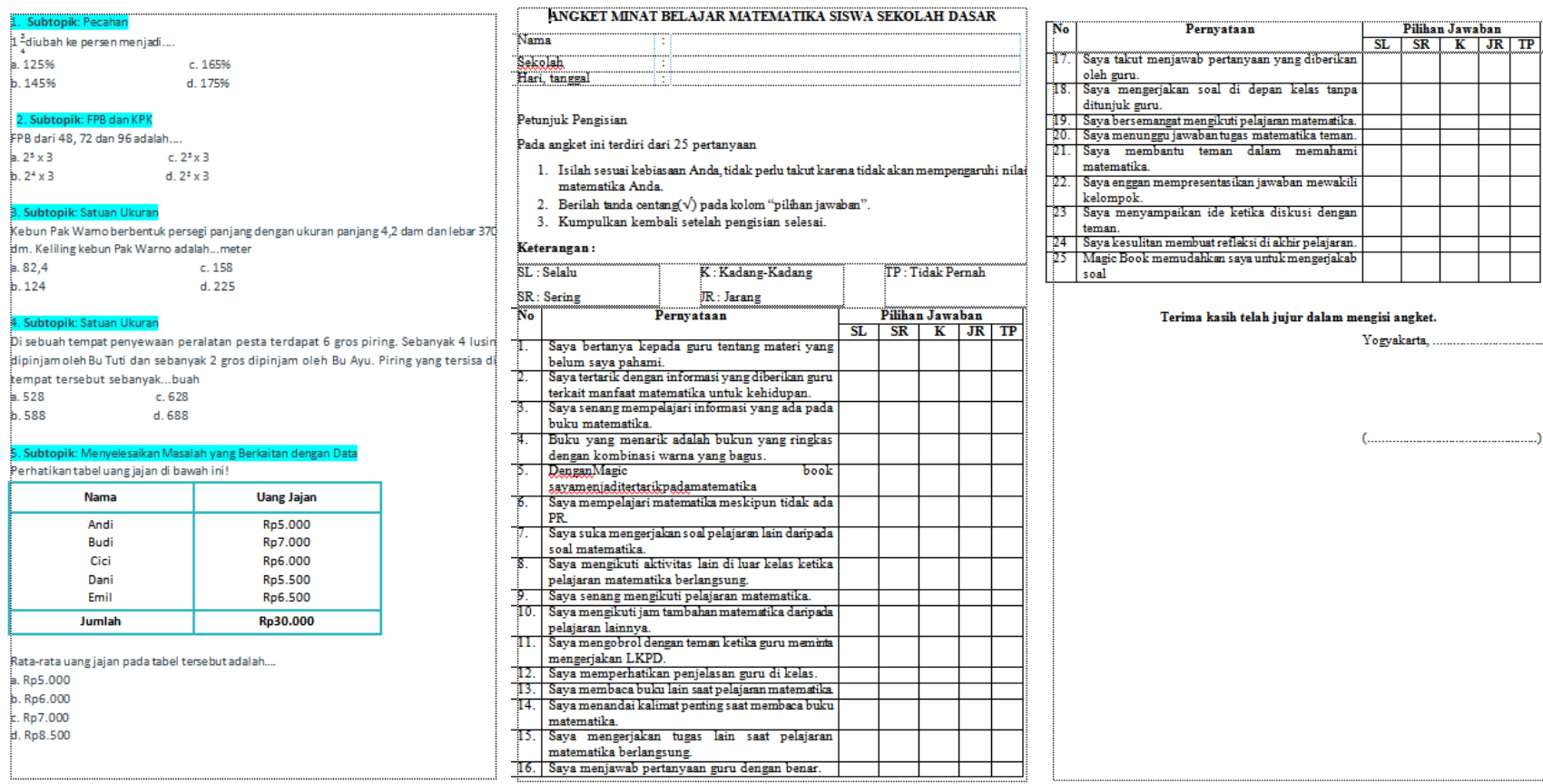

Figure 1. Questionnaire form

From the results of the questionnaire we know that $81 \%$ have a high interest in mathematics and $87 \%$ state that they are interested in magic books and can increase student interest in learning.

\section{CONCLUSION}

Calculated at this stage using the one shot case study experimental model. Giving post-test questions is carried out after the material is given and continued using this magic book learning media. After students work on the post-test questions, according to the results obtained by students that the average value on the work of the post- test questions shows the success of students. This shows that learning that uses magic book learning media is stated to be able to provide good support and effectiveness in the learning process of students.

\section{ACKNOWLEDGEMENTS}

Our gratitude goes to God is Allah because for his gift we were able to complete this paper. In addition to Timoho Study Guidance provided an opportunity to complete this research. So that it is expected to be beneficial to readers and to all parties who we cannot mention one by one. 


\section{REFERENCES}

Daryanto. (2010). Media Pembelajaran (Peranannya Sangat Penting dalam Mencapai Tujuan Pembelajaran). Yogyakarta: Gava Media

Guzel, N., 7 Sener, E. (2009). High school students' spatial ability and creativity in geometry. Procedia $=$ Social and Behavioral Sciences, $1(1)$ 1763-1766.
Ina, V.S. (2012). TIMSS 2011 Intermational Result in Mathematics. New York.

Izzati, R. E., Suadirman, S. P., Ayriza, Y., Purwandari, Hiryanto, \& Kusmaryani, R. E. (1008). Perkembangan Peserta Didik. Yogyakarta: Universitas Negeri Yogyakarta

Tim Redaksi. 2009. Mengajar Matematika Tidak Cukup Hafal Rumus. https://m.republika.co.id 
THIS PAGE INTENTIONALLY LEFT BLANK 